\title{
Subpulmonary Obstruction Due to Aneurysmal Ventricular Septum in a Patient with Congenitally Corrected Transposition of the Great Arteries and Dextrocardia
}

\author{
NAVEEN SHEIKH, SAJAL KRISHNA BANERJEE, MD. ZAHID HOSSAIN, MD. TARIQUL ISLAM, TAHMINA KARIM, \\ ATM IQBAL HASAN, DIPAL KRISHNAADHIKARY, MD NAZMUL HASAN, MD. HARISUL HOQUE
}

Department of Cardiology, Bangabandhu Sheikh Mujib Medical University,Shahbag, Dhaka.

Address for Correspondence: Dr Naveen Sheikh,Assistant Professor, Department of Cardiology, Bangabandhu Sheikh Mujib Medical University,Shahbag, Dhaka. Email: sheikhnaveen@yahoo.com.sg

\begin{abstract}
:
Congenitally corrected Transposition of Great Arteries is usually associated with multiple cardiac defects. Morphologic left-ventricular outflow (pulmonary) tract obstruction due to aneurysm of the membranous ventricular septum in patients with corrected transposition and ventricular septal defect is rare, but was reported in the past. This is even more uncommon in patients with dextrocardia, prompting us to document this case. Absence of the conus with resultant proximity of the aneurysm to the subpulmonary region and higher pressures in the left-sided morphologic right ventricle lead to obstruction of outflow tract in corrected transposition. Echocardiogram with Doppler interrogation and cardiac catheterization with selective cineangiography are the diagnostic tests of choice. Surgical resection of the aneurysm with patch closure of ventricular septal defect, avoiding injury to the conduction system, is recommended.
\end{abstract}

Key Words: Aneurysm, Dextrocardia,Transposition of the Great Arteries.

Introduction:

Congenitally Corrected Transposition of the Great Arteries is usually associated with multiple cardiac defects. Some defects are complex and others are simple, such as atrial or ventricular septal defects. Membranous ventricular septal defects tend to close spontaneously; such closures are usually due to plastering down of one of the leaflets of the tricuspid valve, commonly referred to as formation of aneurysm of the membranous ventricular septum. Rarely, the aneurysmal tissue occluding the ventricular septal defect may prolapse into the outflow tract of the morphologic left ventricle and cause significant obstruction to the pulmonary outflow tract, requiring surgical therapy. We report a case of severe subpulmonary stenosis due to an aneurysm of the membranous ventricular septum in a patient with Congenitally Corrected Transposition of Great Arteries and Dextrocardia.

\section{Case Report:}

A three-year-old asymptomatic male child was referred to us for evaluation of dextrocardia. On cardiovascular examination, the apical impulse was felt in the right midclavicular line at the 5th intercostal space with: right precordial heave, a normal first sound at the right apex, a single second heart sound at right upper sternal border and a grade III/IV ejection systolic murmur best heard at the right upper sternal border. Liver edge was palpable in the left upper quadrant of the abdomen. There were no clinical signs of congestive heart failure.
Chest x-ray (Figure 1) revealed dextrocardia, left-sided liver and left-to-right reversal of bronchi, indicating situs inversus totalis. The electrocardiogram showed negative $\mathrm{P}$ waves in lead I suggestive of atrial inversion and $\mathrm{Q}$ waves in all chest leads (Figure 2).

Echocardiogram revealed dextrocardia with atrial situsinversus, atrio- ventricular discordance, D-loop of

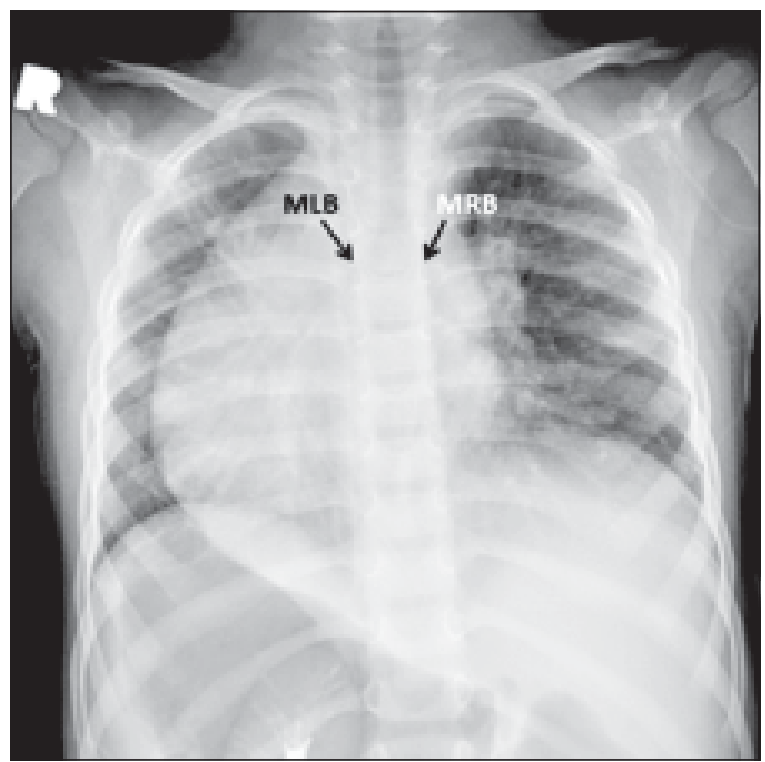

Fig.-1: Chest $X$-ray in posterior-anterior view showing dextrocardia, reversal of right (MRB) and left (MLB) main stem bronchi and left sided liver. 


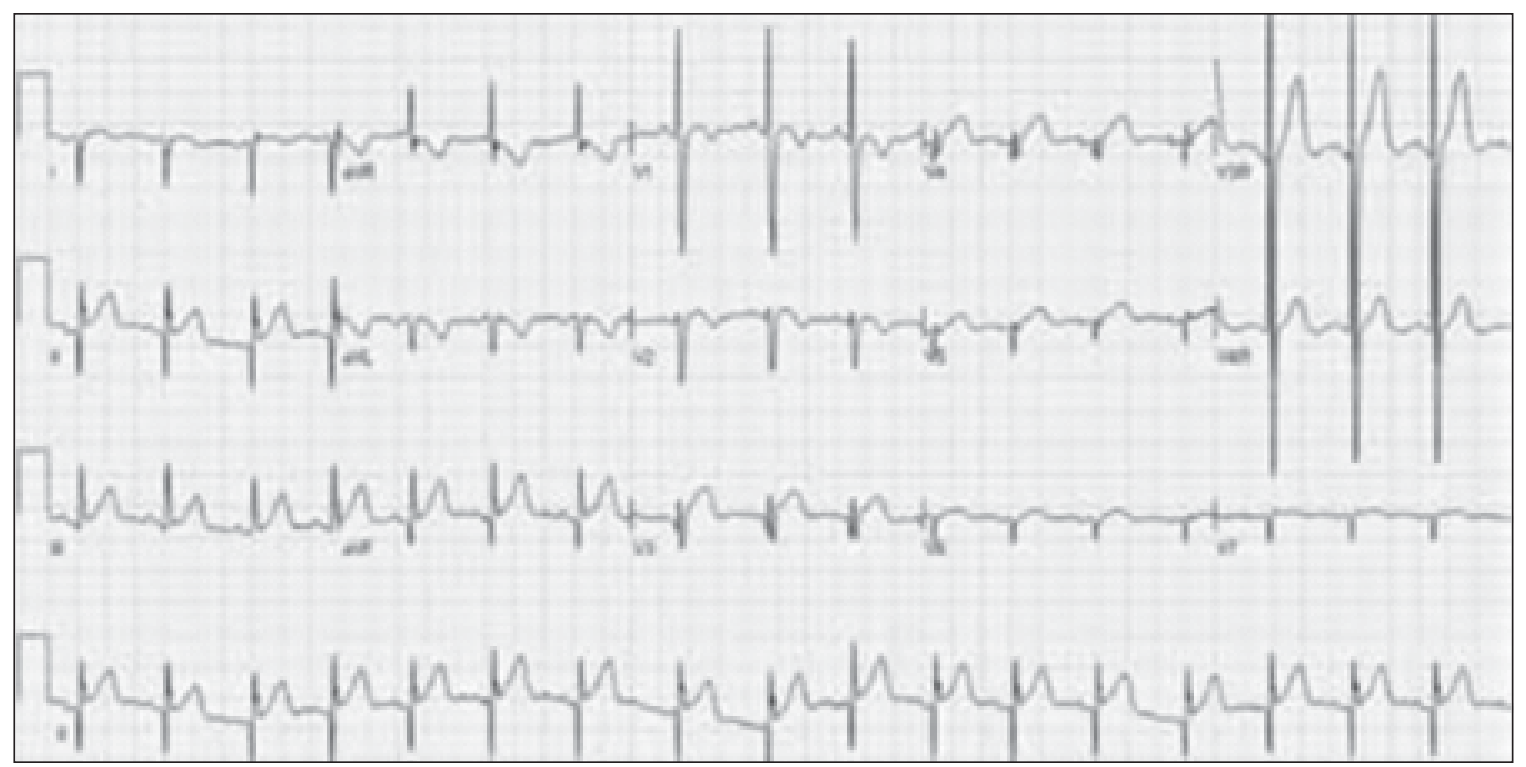

Fig.-2: Electrocardiogram showing negative $P$ waves in lead I suggestive of atrial inversion and $Q$ waves in all chest leads.

ventricles, and ventriculo-arterial discordance. The features are consistent with corrected transposition physiology. There was a moderate-sized perimembranous ventricular septal defect with left-to-right ventricular shunting (Figure 3). There was aneurysmal tissue beneath the pulmonary valve (Figure 4) causing severe sub pulmonary stenosis with a peak Doppler flow velocity in excess of $5.0 \mathrm{~m} / \mathrm{s}$ with a peak instantaneous gradient of $110 \mathrm{mmHg}$ and a mean of $59 \mathrm{mmHg}$ (Figure 5).
Cardiac catheterization and selective cineangiography confirmed the diagnosis of dextrocardia and atrial situsinversus. The left-sided morphologic right atrium was connected to the left-sided morphologic left ventricle which gave rise to the pulmonary artery (Figure 6A). The right-sided morphologic left atrium was connected to the right sided morphologic right ventricle which gave rise to the aorta (Figure 6B). The aortic valve is anterior (not shown), superior (Figure 6) and to the right (Figure 6) of

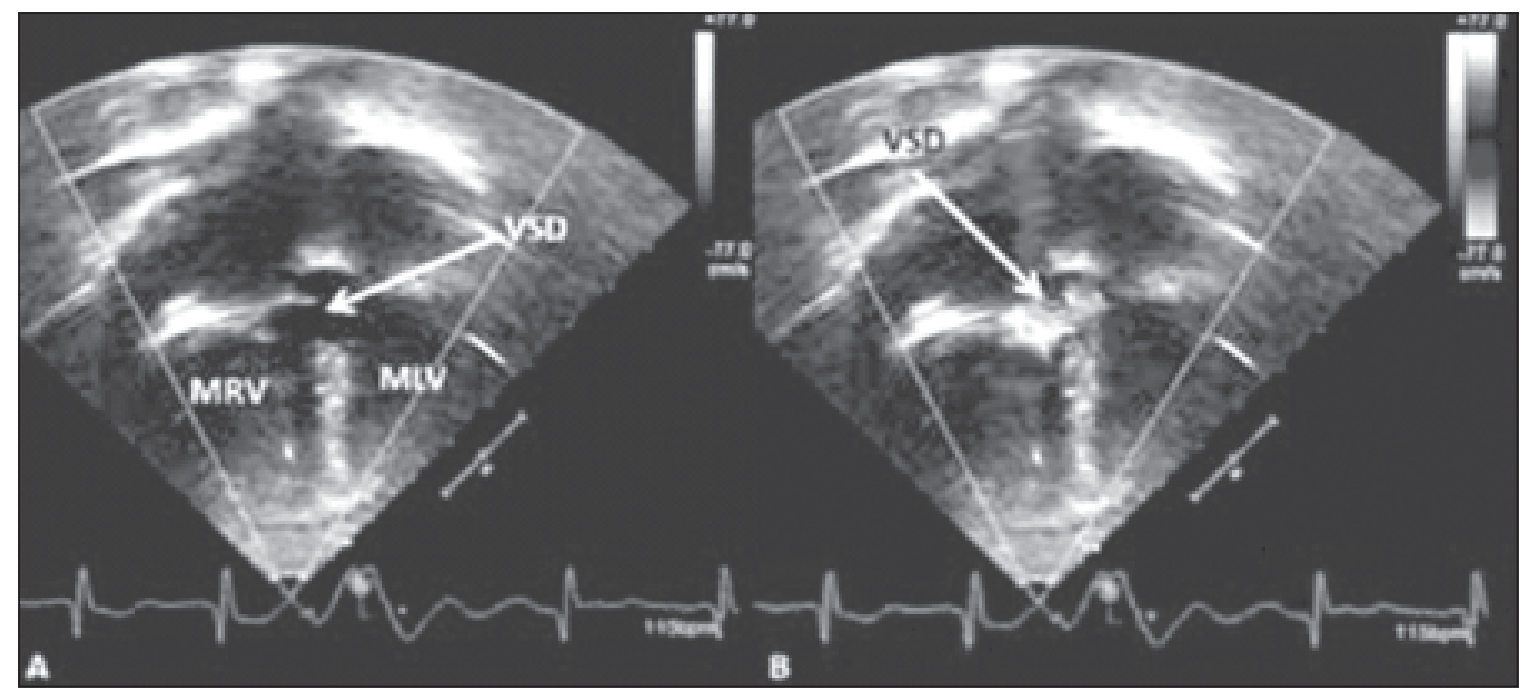

Fig.-3: Two-dimensional (A) and color flow mapping (B) images of apical four-chamber echocardiographic views obtained from the right chest demonstrating moderate to large ventricular septal defect (VSD). MLV, morphological left ventricle; MRV, morphological right ventricle. 


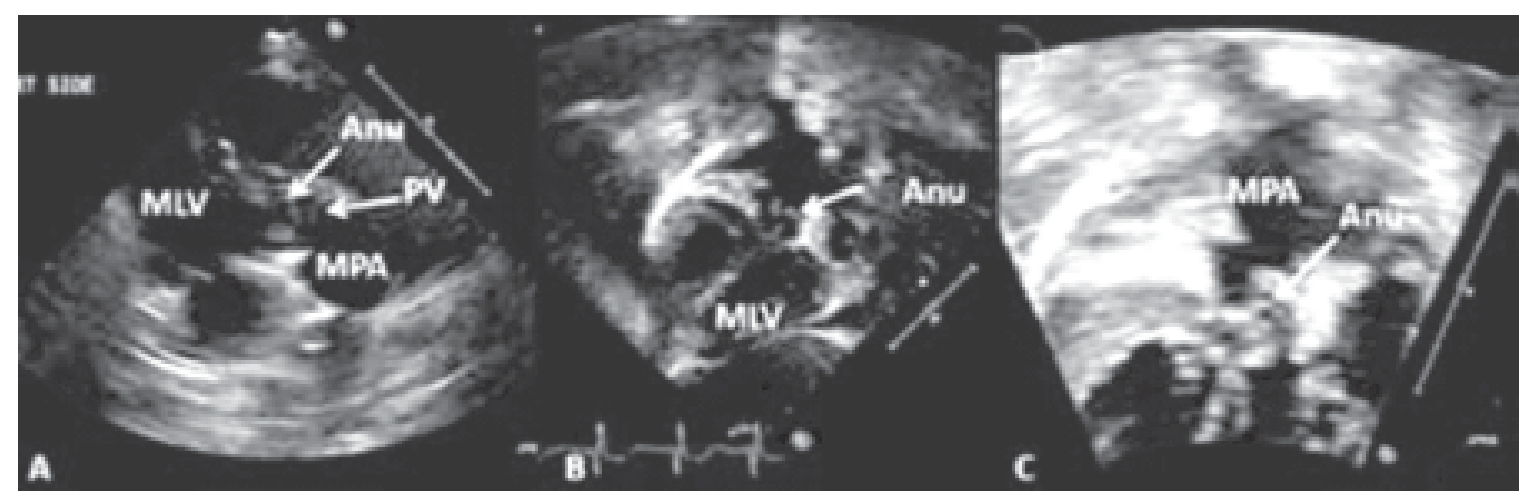

Fig.-4: (A) Selected video frame from a long axis two-dimensional echocardiographic view of the morphological left ventricle (MLV) showing aneurismal tissue (Anu) protruding into the pulmonary outflow tract, causing obstruction. The Anu is located beneath the pulmonary valve (PV). Dilated main pulmonary artery (MPA) is also seen. (B.) The Anu is also demonstrated in the subcostal four chamber view. (C) Magnified view of B, again demonstrating the Anu and dilated MPA.

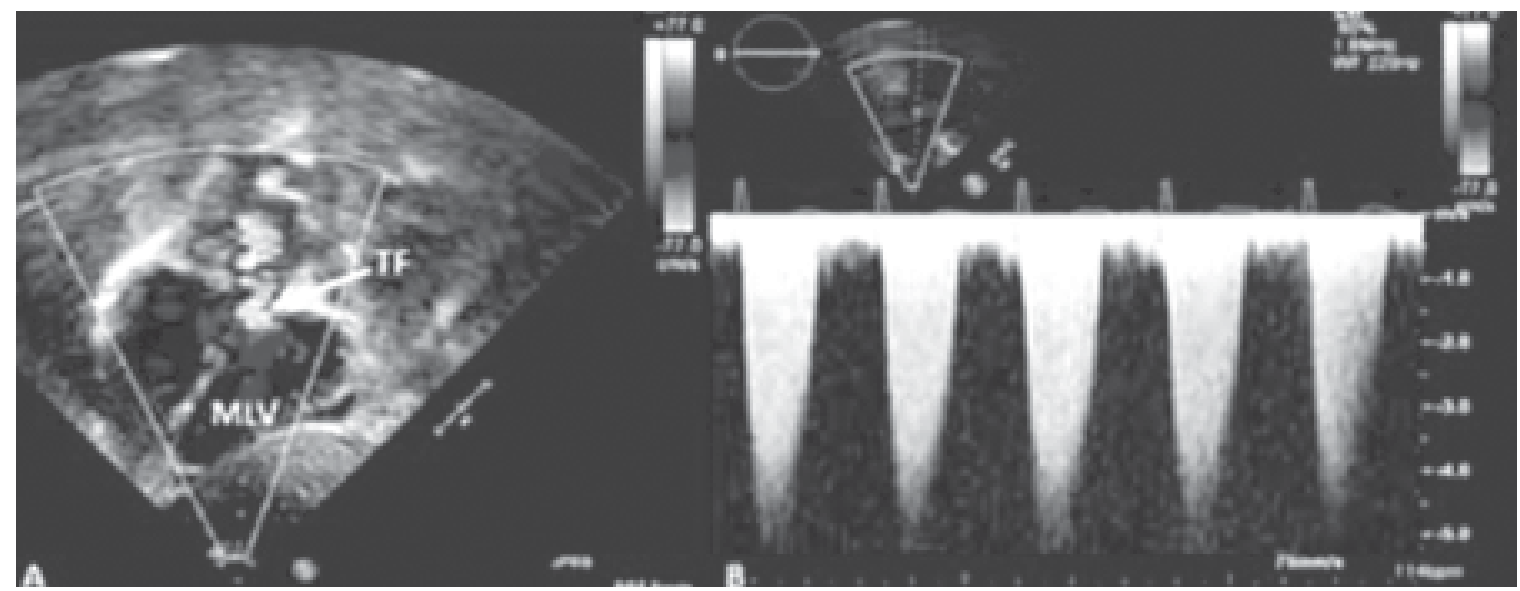

Fig.-5: (A) Selected video frame from a subcostal four chamber view (similar to figure 4B) with color flow mapping demonstrating turbulent flow (TF) in the pulmonary outflow tract. (B) Continuous wave Doppler recording across the pulmonary outflow tract shows peak Doppler velocity in excess of $5 \mathrm{~m} / \mathrm{sec}$ suggesting severe obstruction. See the text for the calculated gradients. MLV, morphological left ventricle.

pulmonary valve (D-loop). These data confirmed echocardiographic findings of corrected transposition physiology. The systolic pressure in the left-sided, morphologic left (pulmonary) ventricle was at systemic level, but pulmonary artery pressure was normal. There was $57 \mathrm{mmHg}$ peak-to-peak systolic pressure gradient across the left ventricular (pulmonary) out flow tract. Rightsided morphologic right ventricular (systemic) and aortic pressures were normal. Selective morphologic left ventricular angiography revealed an aneurysm protruding into the subpulmonary region causing severe outflow tract obstruction (Figures $7 \& 8$ ). There was a moderate-sized ventricular septal defect with left-to-right ventricular shunting (Figure $7 \mathrm{~A}$ ). It was recommended that the patient undergo surgical resection of the aneurysmal tissue along with closure of the ventricular septal defect.
Intraoperative transesophageal echocardiographic findings are consistent with those of the transthoracic echocardiographic and angiographic data. Intraoperative findings were a moderate-sized ventricular septal defect with tricuspid valve tissue prolapsing through the defect forming an aneurysm protruding into the left-sided, morphologic left (pulmonary) ventricular outflow tract. The patient underwent resection of the aneurysmal tissue and closure of the ventricular septal defect with a Dacron patch. He developed complete heart block after the surgery, for which he received a permanent pacemaker at the same time. Currently, he is followed in the pediatric cardiology clinic, and at the last visit eighteen months after surgery, he was asymptomatic, had no residual ventricular septal defect but has mild residual pulmonary outflow tract obstruction with a Doppler peak instantaneous gradient of $30 \mathrm{mmHg}$ and a mean of $16 \mathrm{mmHg}$. 


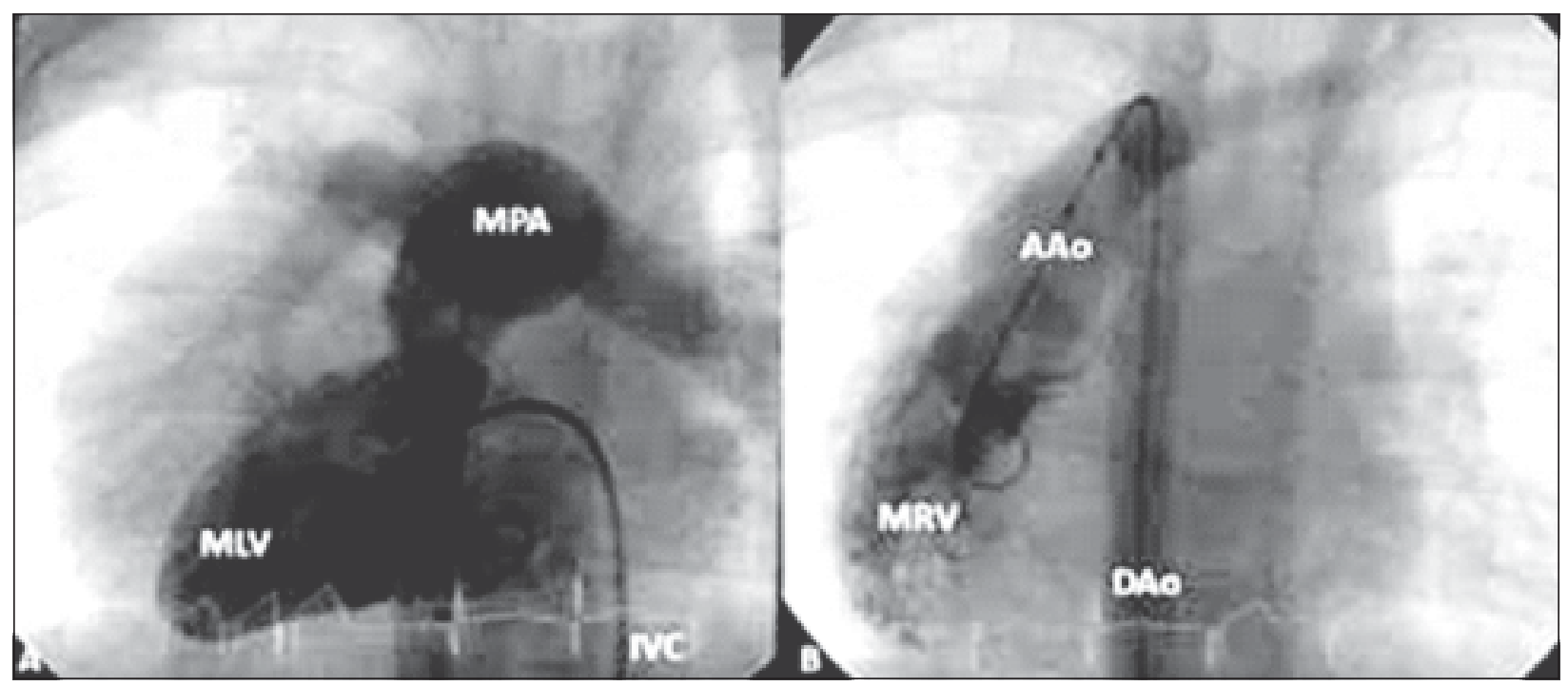

Fig.-6: (A) Selected cineangiographic frame from a left-sided ventriculogram in a posterio-anterior view showing a finely trabeculated, left-sided, morphological left ventricle (MLV) which gives rise to a dilated main pulmonary artery (MPA). Also note that the inferior vena cava (IVC) is on the left of the spine which is connected the left-sided right atrium (not shown). (B) Right-sided ventricular angiogram, also in anterio-posterior view, showing a coarsely trabeculated, right-sided, morphologic right ventricle (MRV) which gives rise to the aorta (AAo). Note that the descending aorta (DAo) ison the right of the spine. The aortic valve is anterior (not shown),superior and to the right of pulmonary valve. These data would indicate D-loop of the ventricle, D-transposition of the great arteries in a subject with dextrocardia, a scenario indicative of corrected transposition physiology.

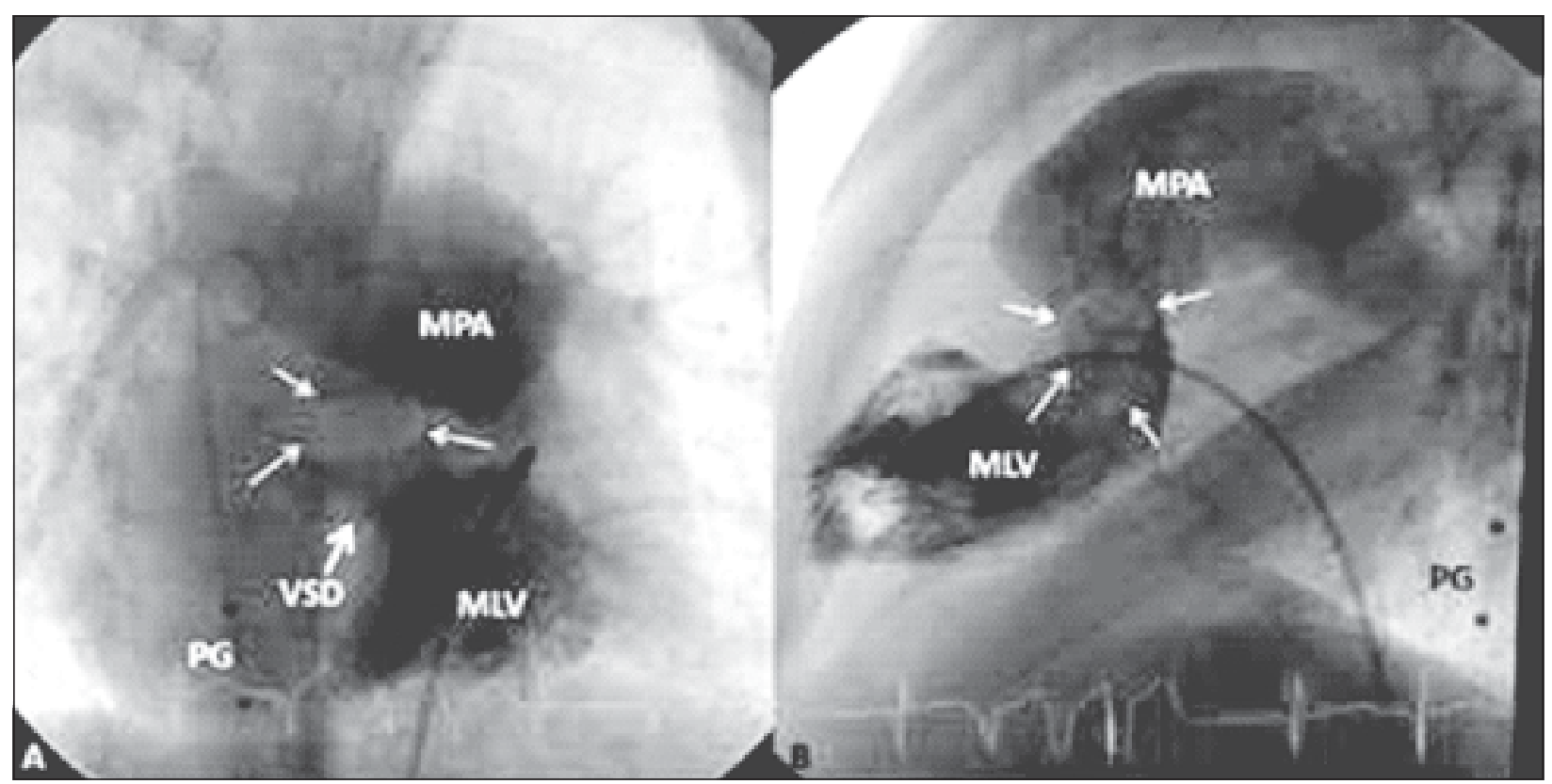

Fig.-7: Selected cineangiographic frames from morphological left ventricular (MLV) angiogram in $60^{\circ}$ left anterior oblique (A) and lateral (B) views showing pulmonary outflow tract obstruction from aneurismal tissue (thin arrows), ventricular septal defect (VSD) (thick arrow) and post-stenotic dilation of the main pulmonary artery (MPA). PG, pigtail catheter in the descending aorta. 


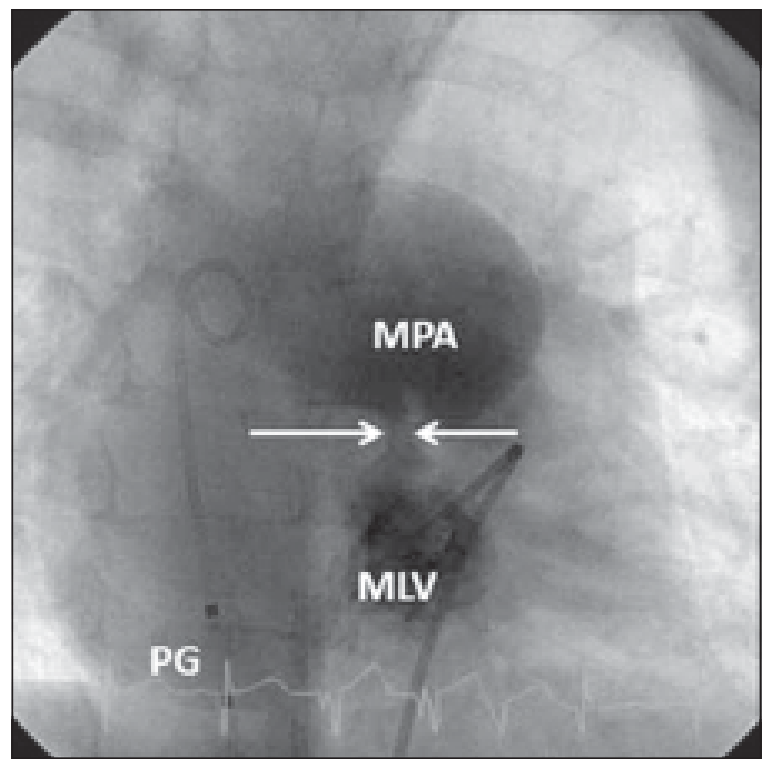

Fig.-8: Selected cineangiographic frame from morphological left ventricular (MLV) angiogram in $60^{\circ}$ left anterior oblique view showing severe narrowing of the right ventricular outflow tract (double arrows) due obstruction from aneurismal tissue (not shown) and poststenotic dilation of the main pulmonary artery (MPA). $P G$, pigtail catheter in the descending aorta.

\section{Discussion:}

Congenital Corrected Transposition of the Great Arteries was originally described by von Rokitansky in $1875{ }^{1}$. Several case series have been reported since 1950 documenting associated lesions and hemodynamic abnormalities. The incidence of this lesion is 1 in 33,000 live births which is approximately $0.05 \%$ of congenital cardiac malformations. ${ }^{2,4}$ The majority are seen with situs solitus and only $5 \%$ are associated with situs inversus, ${ }^{5}$ similar to our case. The hallmark of the lesion is the so called "double discordance:" atrio-ventricular and ventriculo-arterial discordance. Because of this double discordance, the circulatory physiology is normal; systemic venous return goes into the lungs and the pulmonary venous return to the body. ${ }^{6,7}$ The most common anatomical arrangement is levocardia with situssolitus, l-loop of the ventricles and anterior aorta which is located to the left of the pulmonary artery $(S, L, L)$. The less common form is Dextrocardia with situsinversus, d-loop of the ventricles and anterior aorta which is rightward (I,D,D), as in our case. The most common lesions are: Ebstein's malformation of the morphologic tricuspid valve, ventricular septal defect, morphologic left ventricular (pulmonary) outflow tract obstruction and complete heart block. 8,10
Extensive study of the atrioventricular conduction system in corrected transposition with situs solitus patients by several investigators ${ }^{11,16}$ determined that it is abnormally positioned, coursing in the anterior aspect of the subpulmonary tissue and along the anterior rim of the ventricular septal defect. In patients with small or atretic pulmonary trunk and normal septal alignment, the conduction system may consist of dual atrioventricular nodes with sling-like arrangement of conduction tissue. ${ }^{17}$ The location of the atrioventricular conduction system is more variable in patients with situsinversus with corrected transposition physiology; Wilkinson et al ${ }^{18}$ reported that the atrioventricular conduction system is usually situated in the posterior and inferior margin of the ventricular septal defect (anterior node may be present, but does not connect to the ventricular myocardium), in contrast to the superior and anterior location found in corrected transposition of the great arteries in situssolitus. These observations were similar to those reported by Dick and associates ${ }^{19}$ in intracardiac electrophysiological study during surgery and by Thiene et al ${ }^{20}$ in post-mortem hearts. These abnormal courses of the conduction system are of great surgical importance, especially in the presence of a ventricular septal defect or subpulmonary obstruction, since the conduction system is vulnerable to injury during surgical repair of the ventricular septal defect, with the potential for producing iatrogenic heart block, as in our case. Careful review of the location of the conduction system in a given situation (levocardia vs. dextrocardia) and, if necessary, intraoperative electrophysiological definition of the conduction system ${ }^{19}$ may be necessary to prevent such a complication. This lesion is also prone to develop re-entry tachyarrhythmia and varying degrees of heart block. In this review we will focus on morphologic left ventricular (pulmonary) outflow tract obstruction. Issues related to pulmonary outflow tract obstruction in corrected transposition have been addressed in both early and more recent reports. ${ }^{21,27}$

According to these authors the pulmonary outflow tract obstruction is due to several causes, and the most common causes are pulmonary valve stenosis or atresia and subvalvar pulmonary stenosis related to muscular malalignment and/or hypertrophy. Other less common causes are: fibrous tags or accessory valve tissue, ${ }^{28}$ aneurysm of the membranous system, ${ }^{29,34}$ tuberculoma 34 and intracardiac blood cyst. ${ }^{35}$ Pulmonary outflow obstruction due to a prolapsing aneurysm of the membranous ventricular septum is rare, including a detailed clinical, trans- thoracic and trans-esophageal echocardiographic, catheterization and angiographic and 
surgical description of this entity in 1996 in a situssolitus patient by the senior author. Aneurysms of membranous ventricular septum are commonly seen in association with perimembranous ventricular septal defects in patients with normally related great arteries ${ }^{36,38}$ and constitute one of the most common mechanisms by which the ventricular septal defects close spontaneously. Although popularly called "ventricular septal aneurysm," it may not be a true aneurysm, nor derived from the ventricular septum. The origin of the aneurysm is difficult to ascertain even in pathologic studies; these studies suggest that this pouch (aneurysm) is derived either from redundant tricuspid valve tissue or either from membranous septum itself. ${ }^{38,40}$ Even though these closures with aneurysms are beneficial in many patients with ventricular septal defect, sometimes the aneurysms can cause obstruction of the pulmonary outflow tract.

In patients with normally related great arteries, the aneurysm rarely causes outflow tract obstruction due to interposition of the conal septum and crista supraventricularis between the aneurysm and pulmonary valve. By contrast, in patients with Transposition of the Great Arteries who have higher right ventricular pressure, the aneurysm protrudes into the left ventricular outflow tract and causes pulmonary outflow tact obstruction. ${ }^{41}$ Similarly, in patients with corrected transposition, in absence of conal septum and crista supraventricularis in the morphologic left ventricle the aneurysm is closer to the pulmonary valve leading to pulmonary outflow tract obstruction even when the aneurysm is small. According to the previous reports the age of presentation of this condition varies from 5 to 54 years, with a median age of 8 years; most patients were male. Our patient is 3-years-old and is younger than any patient reported so far in the literature. The presentation may be a cardiac murmur in an otherwise asymptomatic patient or symptomatic with chest pain, exertionaldyspnea or easy fatigability. Precordial heave and a single loud second heart sound are present. A loud ejection systolic murmur of pulmonary stenosis at the right upper sternal border and a holosystolic murmur of ventricular septal defect at the right lower sternal border may be heard in patients with dextrocardia. If there is Ebstein's anomaly, a holosystolic murmur due to regurgitation of morphologic tricuspid valve is heard at the apex with radiation to the axilla. Cyanosis and clinical signs of heart failure are uncommon.

Electrocardiogram shows negative $\mathrm{P}$ waves in lead I suggestive of atrial inversion and abnormal Q waves in the chest leads. Chest x-ray confirms the dextrocardia, left-to-right reversal of the bronchi and left sided liver, suggestive of situsinversus (Figure 1). Echocardiogram confirms the diagnosis of atrial inversion, atrio-ventricular discordance, ventricular inversion, and ventriculo-arterial discordance and specific relationship of the great vessels. ${ }^{42,43}$ Echocardiographic studies are also useful in demonstrating aneurismal pouch protrusion into the morphologic left ventricular (pulmonary) outflow tract (Figure 4) and ventricular septal defect (Figure 3). Doppler interrogation quantifies the gradient across the obstruction (Figure 5). Cardiac catheterization is useful as an additional diagnostic tool to accurately measure the peak- to-peak systolic pressure gradient across the pulmonary outflow tract.

Angiography clearly demonstrates the ventricular morphology (Figure 6), location and size of the aneurysm (Figure 7) and of the associated lesions. In the current era cardiac magnetic resonance imaging may be used as an alternative to angiography. ${ }^{44}$ Three-dimensional echocardiogram $^{45}$ is another helpful diagnostic tool. Transesophageal echocardiogram is useful during surgery to reconfirm the diagnosis and to evaluate the extent of relief after surgery. ${ }^{46}$ Treatment of choice is surgical resection of the obstruction and closure of ventricular septal defect, although some investigators used valved conduit to bypass the obstruction. Complete heart block is a common complication for patients with corrected transposition leading some investigators ${ }^{47,48}$ to advocate intra-operative electrophysiological identification of the conduction system. deLeval et $\mathrm{al}^{49}$ described a technique of placing the sutures on the morphologically right side of the septum without opening the systemic ventricle to close the ventricular septal defect and reported no significant arrhythmias related to closure of ventricular septal defect. Various other surgical strategies, particularly doubleswitch, ${ }^{50,53}$ have also been described as ways to restore the morphologic left ventricle to pump against systemic circulation; some physicians ${ }^{54,55}$ consider double-switch preferable to conventional repair.

\section{References:}

1. Von Rokitansky C. Dei Defekte Der Scheidewande Des Herzens. Vienna: Wilhelm Braumuller, 1875:83-5.

2. Ferencz C, Rubin JD, McCarter RJ, et al. Congenital heart disease: Prevalence at live birth. The Baltimore-Washington Infant Study. Am J Epidemiol 1985; 121:31-36.

3. Fyler DC. Report of the New England Regional Infant Cardiac Program.Pediatrics 1980; 65(suppl):376-461.

4. Samanek M, Voriskova M. Congenital heart disease among 815,569 children born between 1980 and their 15-year 
survival: A prospective Bohemia survival study. PediatrCardiol 1999; 20:411-417. 5. Witham AC. Double outlet right ventricle: A partial transposition complex. Am Heart J 1957; 53:928-939.

6. Reddy SC, Chopra PS, Rao PS. Aneurysm of the membranous ventricular septum resulting in pulmonary outflow tract obstruction in congenitally corrected transposition of the great arteries. Am Heart J 1997; 133:112-119.

7. Wallis GA, Debich-Spicer D, Anderson RH. Congenitally corrected transposition.Orphanet J Rare Dis 2011; 14:6-22.

8. Friedberg DZ, Nadas AS.Clinical profile of patients with congenital corrected transposition of the great arteries.A study of 60 cases. N Engl J Med 1970; 282:1053-1059.

9. Allwork SP, Bentall HH, Becker AE, et al. Congenitally corrected transposition of the great arteries: Morphologic study of 32 cases. Am J Cardiol 1976; 38:910-923.

10. Anderson KR, Danielson GK, McGoon DW, et al. Ebstein's anomaly of the left- sided tricuspid valve: Pathological anatomy of the valvular malformation. Circulation 1978; 58:87-91.

11. Anderson RH, Arnold R, Wilkinson JL. The conducting system in congenitally corrected transposition.Lancet 1973; 1:12861288.

12. Anderson RH, Becker AE, Arnold R, Wilkinson JL. The conducting tissues in congenitally corrected transposition.Circulation 1974; 50:911-923.

13. Fischbach P, Law I, Serwer G. Congenitally corrected 1transposition of the great arteries: Abnormalities of atrioventricular conduction. ProgPediatricCardiol 1999; $10: 37-43$

14. Bharati S, McCue CM, Tingelstad JB, et al. Lack of connection between the atria and the peripheral conduction system in a case of corrected transposition with congenital atrioventricular block. Am J Cardiol 1978; 42:147-153.

15. Daliento L, Corrado D, Buja G, et al. Rhythm and conduction disturbances in isolated, congenitally corrected transposition of the great arteries. Am J Cardiol 1986; 58:314-318.

16. Becker AE, Anderson RH.The atrioventricular conduction tissues in congenitally corrected transposition. In: Embryology and Teratology of the Heart and the Great Arteries. Leiden: Leiden University Press, 1978: 29-42.

17. Hosseinpour AR, McCarthy KP, Griselli M, Sethia B, Ho SY. Congenitally corrected transposition: size of the pulmonary trunk and septalmalalignment. Ann ThoracSurg 2004; 77:2163-2166

18. Wilkinson JL, Smith A, Lincoln C, Anderson RH.Conducting tissues in congenitally corrected transposition with situsinversus.Br Heart J 1978; 40:41-48.

19. Dick M 2nd, Van Praagh R, Rudd M, Folkerth T, Castaneda AR. Electrophysiologic delineation of the specialized atrioventricular conduction system in two patients with corrected transposition of the great arteries in situsinversus (I,D,D). Circulation 1977; 55:896-900.
20. Thiene G, Nava A, Rossi L. The conduction system in corrected transposition with situsinversus.Eur J Cardiol 1977; 6:57-70.

21. Rutledge JM, Nihill MR, Fraser CD, et al. Outcome of 121 patients with congenitally corrected transposition of the great arteries.PediatrCardiol 2002; 23:137-145. (Epub 2002 Feb 19).

22. Graham TP Jr, Bernard YD, Mellen BG, et al. Long-term outcome in congenitally corrected transposition of the great arteries: A multi-institutional study. J Am CollCardiol 2000; 36:255-261. 23. Marcelletti C, Maloney JD, Ritter DG, Danielson GK, McGoon DC, Wallace RB. Corrected transposition and ventricular septal defect.Surgical experience.Ann Surg. 1980; 191:751-759.

24. Aeba R, Katogi T, Koizumi K, Iino Y, Mori M, Yozu R. Apico-pulmonary artery conduit repair of congenitally corrected transposition of the great arteries with ventricular septal defect and pulmonary outflow tract obstruction: a 10yearfollow-up. Ann ThoracSurg 2003; 76:1383-1387; discussion 1387-1388.

25. Oliver JM, Gallego P, Gonzalez AE, Sanchez-Recalde A, Brett M, Polo L, Gutierrez-Larraya F. Comparison of outcomes in adults with congenitally corrected transposition with situsinversus versus situssolitus. Am J Cardiol 2012; 110:1687-1691.

26. Yeh T Jr, Connelly MS, Coles JG, Webb GD, McLaughlin PR, Freedom RM, C e r r i t o P B, W i l l i a m s W G. Atrioventricular discordance: results of repair in 127 patients. J ThoracCardiovascSurg 1999; 117:1190-1203.

27. Shin'oka T, Kurosawa H, Imai Y, Aoki M, Ishiyama M, Sakamoto T, Miyamoto S,Hobo K, Ichihara Y. Outcomes of definitive surgical repair for congenitally corrected transposition of the great arteries or double outlet right ventricle with discordant atrioventricular connections: risk analyses in 189 patients. J ThoracCardiovascSurg 2007; 133:1318-1328.

28. Levy MJ, Lillehei CW, Elliott LP, Carey LS, Adams P Jr, Edwards JE. Accessory valvular tissue causing subpulmonary stenosis in corrected transposition of great vessels. Circulation 1963; 27(4 Pt 1):494-502.

29. Summerall CP, Clowes GH Jr, Boone JA. Aneurysm of ventricular septum with outflow obstruction of the venous ventricle in corrected transposition of great vessels. Am Heart J 1966; 72:525-529.

30. Greene RA, Mesel E, Sissman NJ. The windsock syndrome: obstructing aneurysm of the interventricular septum associated with corrected transposition of the great arteries (Abstract). Circulation 1967; 36(Suppl II):25.

31. Falsetti HL, Andersen MN. Aneurysm of the membranous ventricular septum producing right ventricular outflow tract obstruction and left ventricular failure.Chest 1971; 59: 578-580.

32. Krongrad E, Ellis K, Steeg CN, Bowman FO Jr, Malm JR, Gersony WM. Subpulmonary obstruction in congenitally corrected transposition of the great arteries due to ventricular membranous septal aneurysms. Circulation 1976; 54:679-683. 
33. Ignaszewski AP, Collins-Nakai RL, Kasza LA, Gulamhussein SS, Penkoske PA, Taylor DA. Aneurysm of the membranous ventricular septum producing subpulmonic outflow tract obstruction. Can J Cardiol 1994; 10:67-70.

34. Santos CL, Moraes F, Moraes CR. Obstruction of the right ventricular outflow tract caused by a tuberculoma in a patient with ventricular septal defect and aneurysm of the membranous septum. Cardiol Young 1999; 9:509-511.

35. Bliddal J, Christensen N, Efsen F. Intracardial blood cyst causing subpulmonary stenosis in congenitally corrected transposition. Eur J Cardiol 1977; 5:17-27.

36. Varghese PJ, Izukawa T, Celermajer J, Simon A, Rowe RD. Aneurysm of the membranous ventricular septum. A method of spontaneous closure of small ventricular septal defect. Am J Cardiol 1969; 24:531-536.

37. Misra KP, Hildner FJ, Cohen LS, Narula OS, Samet P. Aneurysm of the membranous ventricular septum. A mechanism for spontaneous closure of ventricular septal defect. N Engl J Med 1970; 283:58-61.

38. Freedom RM, White RD, Pieroni DR, Varghese PJ, Krovetz LJ, Rowe RD. The natural history of the so-called aneurysm of the membranous ventricular septum in childhood.Circulation 1974; 49:375-384.

39. Chesler E, Korns ME, Edwards JE. Anomalies of the tricuspid valve, including pouches, resembling aneurysms of the membranous ventricular septum. Am J Cardiol 1968; 21:661668.

40. Tandon R, Edwards JE. Aneurysmlike formations in relation to membranous ventricular septum.Circulation 1973; 47:10891097.

41. Vidne BA, Subramanian S, Wagner HR. Aneurysm of the membranous ventricular septum in transposition of the great arteries. Circulation 1976; 53:157-161.

42. Hagler DJ, Tajik AJ, Seward JB, Edwards WD, Mair DD, Ritter DG. Atrioventricular and ventriculoarterial discordance (corrected transposition of the great arteries). Wide-angle two- dimensional echocardiographic assessment of ventricular morphology.Mayo ClinProc 1981; 56:591-600.

43. Sharland G, Tingay R, Jones A, et al. Atrioventricular and ventriculoarterial discordance (congenitally corrected transposition of the great arteries): Echocardiographic features, associations, and outcome in 34 fetuses. Heart 2005; 91:1453-1458.

44. Schmidt M, Theissen P, Deutsch HJ, Dederichs B, Franzen D, Erdmann E, Schicha H. Congenitally correctedtransposition of the great arteries (L- TGA) with situsinversustotalis in adulthood: findings with magnetic resonance imaging. MagnReson Imaging 2000; 18:417-422.
45. Bartel T, Muller S. Corrected transposition of the great arteries: dynamic three- dimensional echocardiography and volumetry. A new diagnostic tool in intensive care management.Jpn Heart J 1995; 36:819-824.

46. Caso P, Acione L, Lange A, et al. Diagnostic value of transesophageal echocardiography in the assessment of congenitally corrected transposition of the great arteries in adult patients. Am Heart J 1998; 135:43-50.

47. Kupersmith J, Krongrad E, Gersony WM, Bowman FO Jr. Electrophysiologic identification of the specialized conduction system in corrected transposition of the great arteries. Circulation 1974; 50:795-800.

48. Waldo AL, Pacifico AD, Bargeron LM, J a m e s T N, K i r k l i n J W. Electrophysiological delineation of the specialized A-V conduction system in patients with corrected transposition of the great vessels and ventricular septal defect. Circulation 1975; 52:435-441.

49. de Leval MR, Bastos P, Stark J, et al. Surgical technique to reduce the risks of heart block following closure of ventricular septal defect in atrioventricular discordance. J ThoracCardiovascSurg 1979; 78:515-526.

50. Ilbawi MN, DeLeon SY, Backer CL, et al. An alternative approach to the surgical management of physiologically corrected transposition with ventricular septal defect and pulmonary stenosis or atresia.J ThoracCardiovascSurg 1990; 100:410-415.

51. Imai Y. Double-switch operation for congenitally corrected transposition. Adv Card Surg 1997; 9:65-86.

52. Imai Y, Seo K, Aoki M, Shin’oka T, Hiramatsu K, Ohta A. Double-Switch operation for congenitally corrected transposition. SeminThoracCardiovascSurgPediatr Card SurgAnnu 2001; 4:16-33.

53. Ilbawi MN, Ocampo CB, Allen BS, et al. Intermediate results of the anatomic repair for congenitally corrected transposition. Ann ThoracSurg 2002; 73:594-599; discussion 599-600.

54. Langley SM, Winlaw DS, Stumper O, et al. Midterm results after restoration of the morphologically left ventricle to the systemic circulation in patients with congenitally corrected transposition of the great arteries. J ThoracCardiovascSurg 2003; 125:1229-1241.

55. Shin'oka T, Kurosawa H, Imai Y, et al. Outcomes of definitive surgical repair for congenitally corrected transposition of the great arteries or double outlet right ventricle with discordant atrioventricular connections: risk analyses in 189 patients. J ThoracCardiovascSurg 2007; 133:1318-1328. 